\title{
The portrait of an Iranian as an English Language Learner: A case of identity reconstruction
}

\author{
Khatib, Mohammad \\ Department of English Language and Literature, Allameh Tabataba'i University, Iran (mkhatib27@yahoo.com) \\ Rezaei, Saeed \\ Allameh Tabataba'i University and Sharif University of Technology, Iran (srezaei@ sharif.edu)
}

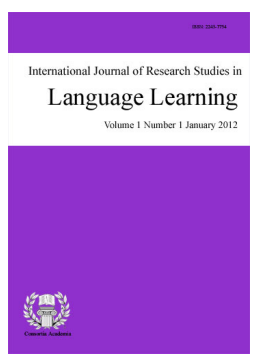

ISSN: $2243-7754$ Online ISSN: 2243-7762

OPEN ACCESS

\begin{abstract}
This is a case study exploring an Iranian English language learner's identity within the Iranian EFL context and its potential relation with the success/failure and age of the learner. Also the learner's inclination to his Persian identity, cultural norms, values and pronunciation patterns is investigated. In order to do so, in-depth interviewing and ethnographic observation were employed. The data collection and analysis procedure occurred between February and April, 2011 in Tehran. After the data were collected through interviewing and field notes in the ethnographic observation, they were transcribed and later turned into the participant's life story. Important themes were dug out of the data using narrative analysis. The emerging themes from the current study were revealing about the participant's identity and gave a portrait of the participant as an Iranian English language learner and his identity. Finally, the implications, limitations and future directions for this study are discussed.
\end{abstract}

Keywords: case study; ethnographic observation; identity; interview; Iran(ian); language 


\section{The portrait of an Iranian as an English Language Learner: A case of identity reconstruction}

\section{Introduction}

With the rise of globalization and the importance of English as an international language, the majority of people in the whole world have felt the urge to learn English. This gradual but consistent desire to learn English has raised certain potential sociolinguistic and sociological concerns, one of which is pertinent to the identity of language learners after being exposed to English as a Foreign/Second language. Different positions are held by different scholars but the most favorable one is the move toward transnationalism and avoiding dogmatic nationalism. By transnationalism it is meant to possess the norms and values of both your own and target language and culture and hence develop a more complete self.

As current publications and journals indicate (e.g. Journal of Language, Identity, and Education) research in applied linguistics has oriented more toward sociocultural/sociolinguistic issues affecting language learning. This is what David Block (2003) calls 'the social turn in SLA'. These social concerns mainly discuss how language, culture, identity, ideology, globalization, power, and hegemony can affect our educational system. One of these factors recently receiving maximum attention is identity and how it can affect language learning and teaching. The literature indicates that we have different types of identity including language, cultural, social, gender, ethnic, racial, and national identity among many others. In this study the main attention is given to language and cultural identity.

According to Block (2007b), language identity can be understood 'as the assumed and/or attributed relationship between one's sense of self and a means of communication which might be known as a language (e.g. English) a dialect (Geordie) or a sociolect (e.g. football-speak)' (p. 40). Norton (1997) on the other hand describes cultural identity as '... the relationship between individuals and members of a group who share a common history, a common language, and similar ways of understanding the world' (p. 420).

\section{Theoretical framework of the study}

This research is mainly informed by poststructuralist and post-colonial theories of language and education. Below these two theoretical standpoints with their central underlying tenets related to the current study are explained.

\subsection{Poststructuralist theories of language}

Like many other "post" something in philosophy and social theory, poststructuralism refers to the theories evolving after structuralism. In other words, poststructuralism is built upon the structuralism but is distinct from it (Norton, 2011). In fact, one of the main shortcomings of structuralist theory was its inability to account for the social aspect of signs and languages in general. In poststructuralism, language system is considered to be dynamic and instable rather than preformed and prescribed. Poststructuralist view of language proposed by theoreticians such as Mikhail Bakhtin (1981) consider language as a dialogically occurring phenomenon in which meaning is created not devoid of context but in dialogism.

Another poststructuralist view on language is related to French sociologist Pierre Bourdieu who considers language as a symbolic power in language and how this power is disseminated in discourse (Bourdieu 1977, 1991). Bourdieu's work is related to the study of language in that he not only takes language merely as a tool for communication but also a mechanism of power. In other words, the position each individual has in society envisages a certain degree of power in the people around him/her and ultimately defines the individuals' rights to 
speak, to be listened to, to be interpreted, and to be analyzed. Bourdieu (1977) strongly believes in the unequal sharing of talking right among interlocutors based on their power.

Next influential theoretician from feminist poststructuralist tradition is Christine Weedon (1997) whose works go similar to those of Bakhtin and Bourdieu. She uses the term subjectivity to distinguish herself from other theoreticians. By subjectivity Weedon (1997) means 'the conscious and unconscious thoughts and emotions of the individual, her sense of herself, and her ways of understanding her relation to the world' (p. 28). Similarly for Weedon social interaction is the main tool showing how individuals are constructed. Similar to other poststructuralist theorists, she emphasizes the importance of subjectivity and identity as being diverse, dynamic, and changing. In this way Weedon's views are close to those of Foucault for whom subjectivity is said to be discursively constructed rather than in vacuum.

According to Pavlenko (2002, p. 282) within applied linguistics research, the root of poststructuralist inquiries can be traced in the critical applied linguistics works of Pennycook especially when he stated that we 'need to rethink language acquisition in its social, cultural, and political contexts, taking into account gender, race, and other relations of power as well as the notion of the subject as multiple and formed within different discourses' (Pennycook, 1990, p. 26). As Pavlenko clarifies, this need was later more deeply dealt with through Bonny Norton's works (e.g., Norton, 1995). This research is theoretically informed by poststructuralist view of language because it can provide complementary approaches to the study of language and culture in ELT (Morgan, 2007). Accordingly, it is related to this theoretical stance in that it argues how the identity of an individual is reshaped from the time he started to learn English and hence confirming the dynamicity of language and identity.

\subsection{Post-colonialism and language education}

Post-colonialism is based on how power relations are distributed between Western and Third World countries as a tool to impose their oppression. In other words, there will be an asymmetric power relation between the self and other. According to Ashcroft, Griffiths, and Tiffin (1998) post-colonialism, hyphenated or not, relates to:

the study and analysis of European territorial conquests, the various institutions of European colonialisms, the discursive operations of empire, the subtleties of subject construction in colonial discourse and the resistance of those subjects, and, most importantly perhaps, the differing responses to such incursions and their contemporary colonial legacies in both pre and post-independence nations and communities (p. 187).

In general post-colonialism tries to critique the western norms and unravel the potential sources of hegemony and illegitimate power in language, culture, ethnicity, discourse, etc. The main scholars who have triggered the widespread approval and attraction of post-colonial studies are Edward Said, Stuart Hall, Homi Bhabha, Leela Gandhi, Paul Gilroy, and Gayatri Spivak. This theory is mainly based on the idea of self and the other which spawned in the 1970s with the publication of Edward Said's book Orientalism based on Foucauldian paradigm. This theory subsequently led to what was later called "colonialist discourse theory" in the work of critics such as Gayatri Spivak and Homi Bhabha (Ashcroft, Griffiths, \& Tiffin, 1998; p. 186).

English language teaching has been a good colonizing tool and English language itself is the language in which colonialism is mostly written in (Pennycook, 1998). Through colonization, the most important element colonized is the language and culture of the colonized region. In order to do so, language becomes the tool for colonizing the world through the western ideology. Since language and culture are two integral elements in our identity, the colonizer can usurp the language and culture of the colonized and supersede them with the language and culture of the west as superior. By doing so, people are alienated from their root ethnicity, language, and culture and subsequently their identities are also reconstructed. This alienation occurs when the colonized, i.e., the other, feels to be inferior to the colonizer, i.e. the self. 


\section{Review of literature}

With the emerging mass publications on identity (e.g. Block, 2003, 2006, 2007a; Joseph, 2004; Norton, 2000; Pavlenko \& Blackledge, 2004; Riley, 2007), this line of research has become very attractive especially in multilingual and multicultural contexts. There are many factors considered to be influential in the formation of individuals' identities including their age, years of study, first language and ethnicity among many others. David Block (2007a) in his seminal paper categorizes research on identity into three distinct groups based on the context of the study namely: naturalistic, foreign language, and study abroad. Block sees Firth and Wagner's (1997) study as the sparkling point in triggering studies on identity. Norton's seminal book entitled 'identity and language learning' published in 2000 is considered the first and pioneering work in which identity is investigated within the naturalistic setting. Norton (2000) studied the identity of five immigrant women who had just arrived in Canada. The main objective of her study was to investigate the interrelations between identity, power, and access to English language in classroom and outside.

Another case study focusing on immigrant adult learners is by Teutsch-Dwyer (2002) and is related to Karol, a Polish immigrant in California. Karol was a 38-year-old immigrant moving to California. The data collection procedure included recording Karol's naturally occurring words bimonthly, observation, interviewing both Karol and his coworkers and girlfriend. The results of the study indicated that Karol's English language proficiency developed minimally after 14 months of data collection. The main reason for this lack of language development was Karol's inability to establish a good gendered identity in relation to others in the U.S. In other words, he failed to establish a good relation or rapport with other men in the U.S. but was successful in doing so with women.

Morita (2004) also found that the six female L2 Japanese graduate students in a Canadian University showed reluctance concerning being labeled as a 'relatively silent group', 'non-native speakers', and 'students with deficit' by their teacher. Ibrahim (1999) also investigated hip-hop culture among a group of French-speaking African immigrants in Canada who were mesmerized by Black English and subsequently invested in Black-stylized English. What seems to be clear from the studies conducted so far is that the majority of studies investigating language learners' identity has been done in settings where English is the main means of communication, i.e. in second language contexts. These studies (e.g. Belz, 2002; Kanno, 2003; Norton, 1995 , 2000; Pavlenko, 2003) mainly focused on immigrants' language and identity (re)construction within the host country. However, literature shows that relatively few studies have been conducted in EFL contexts and to the best of our knowledge this line of research is under-researched in the Iranian EFL context. Subsequently, this study is to explore the following research questions:

1. How is the identity of an Iranian English language learner related to his degree of success or failure according to his general language proficiency?

2. How may have the age of Reza affected his identity?

3. Does Reza try to follow his L1 pronunciation patterns revealing his Persian identity or he regards Standard English spoken in Anglo-American countries as the norm? Which accent does he favor more? And why?

4. Which culture does he favor to be exposed to when learning English, Persian or English? And why?

\section{The current study}

\subsection{Participant}

The only participant in this study was Reza who had been a friend of one of the researchers for a long time. Since this study was after investigating a delicate and intricate feature of Reza's personality, his consent was 
taken at the outset of the study. In order to avoid any possible ethical violations, he was informed of the purpose of the study and he was also assured that his privacy would be kept confidential and even his name would be used as fictitious, though he did not have any problems with having his real name included in the study.

\subsection{Research design}

Research design, tools and methods are very important in researching identity. As Rezaei (2012) clarifies, there are different research designs, tools, and methods to research identity in language studies and the main research designs suitable are qualitative and mixed-methods. For the purpose of this study, a qualitative case study was employed to explore an Iranian English language learner identity. According to Yin (2003), case study is one of the ways of doing research in social science and is the "preferred strategy when "how" or "why" questions are being posed and when the researcher has little control over events, and when the focus is on a contemporary event within some real-life context', 'especially when the boundaries between phenomenon and context are not clearly evident' (p.1 \& p.13).

\subsection{Instrumentation}

In order to collect the required data in this study, the researchers employed in-depth individual interviewing and ethnographic observation with field notes.

\subsubsection{In-depth interviewing}

In-depth interviewing was run in two distinct stages of the research; the first one was run at the beginning of the study and mainly focused on the past experiences of Reza. It should also be mentioned here that all the interviews were held in English so that the participant could better be his English-speaking individual when talking with the interviewer. In this stage, narrative stories from Reza revealed his past life and self. The main questions asked in this stage focused on the participant's past language learning experiences, his family background, and language and cultural identity (see appendix A).

In order to reduce the effect of the information communicated between the researcher and the participant in the first interview, the second interview was run one month later. In the second interview, the researchers asked about the present status, self, and identity of the participant. This stage focused on how Reza's identity might have changed after embarking on language learning journey, and how far he thought he had changed after opting English as his second language (see Appendix B).

\subsubsection{Ethnographic observation}

As a research tool in anthropology and sociology, ethnography is a participatory type of research which enables researchers to observe events as they happen at a research site. This feature helps researchers to get a more vivid picture of what each individual does and finally emically report his/her data (Duff, 2008). In ethnography, data collection is fulfilled through participant or nonparticipant observation, interviews, questionnaires, ethnographers' diaries and field notes, films and audio recordings, authentic documents, etc. (Rezaei, 2012) and consequently triangulation is achieved in research. According to Rezaei (2012), the main features of ethnographic studies are:

"The events in ethnography are interpreted from the subjects' point of view. However, striking a
balance between an emic and etic perspective is difficult and can be considered as a drawback to
ethnography. There must be a prolonged engagement in the research site with the subjects in
order to reach a full picture of the phenomenon under study, i.e. thick description” (p. 47).

Ethnographic observation was particularly fulfilled in this study by getting close to the participant, i.e. Reza, and by going out with him, and inviting him over. The main purpose of doing so was to gain a detailed and thick description of the participant's identity. The data gathered through ethnographic observation were used to write 
Khatib, M. \& Rezaei, S.

Reza's life story and were subsequently helpful for analyzing the data and interpreting Reza's ideas.

\section{Data collection and analysis}

This study was done between February and April 2011 and followed a qualitative research design. In order to reach a better source of data and have trustworthiness and reliability, triangulation was executed by having both interviews and ethnographic observation. Meanwhile, the researcher had an ethnographic approach by being with Reza as the only participant of the current study for a while and hence getting a better portrait of what he was like.

Data analysis started as soon as the data were collected. In other words, data analysis was done in parallel with data collection. The first stage was the transcription of the data. Based on the data transcribed and elicited via individual in-depth interviews, a life story (Lieblich, Tuval-Mashiach, \& Zilber, 1998) was made and written. In other words, a life story was written for Reza as an individual in this study.

After writing Reza's life story, the researchers dug out the themes relevant to the purpose of the study and the research questions posed in this study. In order to fulfill this purpose, the researcher printed the participant's story and then highlighted the parts of the stories relevant. Accordingly important words, clauses, and sentences were coded for the themes to be identified and narrative inquiry was used as a tool to analyze the data.

Narrative inquiry is one of the most helpful qualitative research methods to investigate identity. In narrative inquiry, participants tell a story and talk about an event in their lives freely (see Bell, 2002; Clandinin \& Connelly, 2000; Pavlenko, 2007). Pavlenko (2001) proposes narrative inquiry as a research method to inquire into social identity. She states that:

\section{"L2 learning stories...are unique and rich sources of information about the relationship between language and identity in second language learning and socialization. It is possible that only personal narratives provide a glimpse into areas so private, personal, and intimate...and at the same time at the heart and soul of the second language socialization process" (p. 167).}

In this study the researchers were after emerging themes that were construed from the participant's life story through narrative inquiry. In order to fulfill such an aim, the participant was interviewed regarding his past and present in order to delve into and elicit his identity. In this part the data from Reza's life story are presented in the form of a vignette and then analyzed by referring to some excerpts from his interviews.

\subsection{Reza's narrative life story}

Reza was a 26-year-old boy from a well-educated family and held a B.S. in Petroleum Engineering. His English proficiency according to the TOEFL test given to him and also the interview by one of the researchers in this study was found to be upper-intermediate to advanced. He was born and bred in Bushehr ${ }^{1}$ but had recently moved to Tehran with his family. Regarding his academic background in English, he stated that he had started learning English at the Iran Language Institute in Bushehr when he was almost 16 years old. However, he had quit learning English for four years and then had resumed learning English at language institutes and IELTS classes. When asked if he had been abroad he said that he had only once been out of Iran to Dubai for a week on a business trip and as he confirmed he had found the experience very interesting. He was motivated a lot communicating with English native speakers there.

As shown in excerpt 1, he expressed that he had found himself ahead of his friends who did not know English because of the technological growth and the need to communicate in English. He also found speaking English as being a credit for being prestigious.

\footnotetext{
${ }^{1}$ It is a small city in Southern Iran lying next to the Persian Gulf
} 


\section{Excerpt 1}

I feel I am superior and more powerful when speaking English and I feel being more successful in my career too. I owe all this to my English proficiency.

As revealed in excerpt 2, regarding Persian language and his idea about English or Persian he stated that he favored English classes over his Persian classes because he found English classes more interesting and useful.

\section{Excerpt 2}

I like Persian poetry, literature, and art but I feel more amused with English. I find it more amusing to understand a new culture and language.

With regard to the culture of different Englishes, he maintained that he favored American English over other varieties of English due to the attraction it had for him. He even voiced his opinion that American culture was superior to many other cultures! He found American culture intriguing. And he remarked that he had even tried to be like Americans and imitate what they do as part of their culture. However; when it came to his nationality, he persisted that he never gave up his national identity as an Iranian and he would never feel degraded to introduce himself as an Iranian when abroad (e.g. in the U.S.).

\section{Excerpt 3}

I don't like British English...I think it's full of façade and it sounds kinda phoney to me! I love my own country Iran and I am proud of it and its people...but I also love American language and culture. I guess most of these attractions are because of the western media for me. I watch movies a lot and feel very much attached to them.

He further acknowledged that he honored American accent more and believed that British English was not sweet to the ear and American English was very nice. And he responded that he did not like listening to lectures spoken with Persian accent because he felt irritated then (see excerpt 4).

\section{Excerpt 4}

When I was an English student I always did my best to imitate American English pronunciation patterns. I mimicked their facial and pronunciation norms....about Persian pronunciation I should say I hate speaking English with Persian or any other places' accent....

When it came to his personality change, he expressed that he had changed a lot since he had started learning English. He mentioned that he started feeling more confident and different since then. He believed that he felt greater after learning English (see excerpt 5).

\section{Excerpt 5}

When I think back to those days when I had just started English, I realize I have changed a lot (pause).... I can't say for sure these changes have been for my English classes but I think it has affected my personality and behavior dramatically.

Since Reza was very interested in movies, he thought this appeal motivated him to learn English. Also he held that he had a group or community of friends sitting together and trying to speak English all together (a piece of evidence for imagined community) (see excerpt 6).

\section{Excerpt 6}

I frequently go out with my friends and try to speak English...I usually fantasize living abroad or studying there...It inspires me a lot to practice more. 
He insisted that learning English had opened new horizons in front of him and he reasoned he had changed a lot since starting to learn English. For his identity change since learning English, Reza discovered that this change in his identity had been very effective and helpful. He had learnt a lot after being able to communicate with people from other countries. He had even learnt how to respect others by communicating with foreigners! (see excerpt 7).

\section{Excerpt 7}

...I think this change in my personality and behavior has been good for me and pushed me ahead...

When asked about which culture he favored, he said he liked Western cultures to be included in textbooks and for language learning (see excerpt 8).

\section{Excerpt 8}

...when you wanna swim you should swim in water, you can't swim in desert...I think I can't learn English without learning about its culture...I also believe American culture speeds up my language learning.

\subsection{Emerging themes and Reza's identity}

After reading Reza's life story by transcribing the interviews and also referring to the field notes gathered via participatory ethnography and observation; certain words, statements, and ideas were highlighted due to their relevance to the purpose of the study. With regard to the first research question, i.e. identity and the degree of success and failure, it is clear from Reza's story that he had a strong inclination toward the Western culture. This desire to be assimilated and identified with Americans was a driving force for him to study harder. He even envisaged an imagined community (see Norton \& McKinney, 2011 for more information on imagined community and identity) and invested his time and money on learning English (see Norton, 2000 for more information on investment). These are all in line with Norton's notions of identity, investment, and imagined community. In brief, he was an upper-intermediate to advanced level student and the researchers here believe that his proficient English American pronunciation was partly, if not wholly, due to Reza's orientation toward American culture and language and the strong desire to be like them. This is also concluded from his own words in the interviews.

Besides, as Reza declared in his narrative life story he was twenty six years old and he must have been mature enough at this level to have a critical reflection on such notions as identity. Though he was somehow reluctant about some norms in his own country, i.e. Iran, he was generally interested in his own language and culture and also liked American values and culture. This preference speeded up his getting closer to the American pronunciation norms and patterns. This is in line with the dynamicity of identity and it could be discerned from the interviews that Reza revealed a different identity when speaking English from the time he spoke Persian. So the language spoken also affected the way the participant behaved.

When he was asked about his pronunciation preference, he indicated that he preferred American English more and detested speaking with a Persian accent. Hence, local version of English was not admired by Reza. He even said that he liked to listen to lectures spoken with pure American pronunciation and even his role model in Iran, Abbas Kiarostami, speaking with a Persian accent could not be tolerated by him though the main purpose would be the communication of meaning and information. All in all, he was determined about his stance regarding his enthusiasm toward American English and did not favor a localized pronunciation revealing his Persian identity. However, it should be mentioned that he did not feel it beneath his dignity to be labeled as a Persian when abroad, showing the maintenance of his national identity. All the evidence here acknowledges the point that Reza considered himself as other from a post-colonial perspective. In other words, the west was the 
idol for him and made him think of himself, his language, and identity not as equal to the western ones.

Moreover, he showed a longing for American culture and approved that he liked learning more about American culture and also confirmed that he preferred learning English via the medium of Western culture rather than Persian culture. And his main reason as above was that he esteemed American culture and was attracted to it. All the themes emerging from the data confirm that Reza had gone through a change since he had been exposed to the Anglo-American language and culture through the textbooks, movies, and people he had interacted with. Certain ideologies were inculcated on him and were internalized in his mentality regarding his own sense of being as an Iranian.

\section{Discussions and educational implications}

The results of this study can be helpful on a number of grounds; first and foremost to shed light on a number of issues related to linguistic identity of the Iranian English language learners. The findings of this study can contribute to our understanding of identity and good language learners. This is an under research topic not pursued in the Iranian EFL context. Since identity is closely correlated with the idea of motivation, the results can be helpful to our better judgment about good language learners. Hence identity as a broad individual-differences factor can be very informative in our teaching practice, materials development, policy making, and assessment and evaluation of our individual learners in language classes depending on their individual identities.

In addition, the results of this study can move us away from a merely psycholinguistic perspective to a sociolinguistic perspective in SLA and can also clarify the possible roles of society, power, and investment as social factors in L2 learning. This sociolinguistic standpoint toward L2 learning is believed to be more comprehensive about our language learners adopting a qualitative research paradigm.

In tandem with Norton's studies (1995, 1997, 2000), the results of this study reveals how far investment and the construction of imagined communities can contribute to the development of L2. Norton (2000) believes that learners' identity change when learning L2 by investing for learning which is definitely crucial in accelerating the process of L2 learning and approximating oneself to L2 norms. In other words, the results of this study can show how far language learners' membership or access to certain social networks and communities (e.g. L2 speaking communities through the media, inclination to the Western culture, etc.) can contribute to their success in L2 learning.

Moreover, the results of this study are helpful in flourishing a mood of transnationalism where people have a critical and reflective understanding of diverse cultures, and languages and at the same time value their own language and culture. In other words, the current researchers are against monocultural instruction only focusing on the home or host countries' cultural norms. Instead, we can teach cultural norms with a critical thinking approach in a way so that we can reduce the risk of identity crisis in our learners. The results of this endeavor can be critically revealing and helpful in our Iranian language learners' cultural, ethnic, and linguistic norms and stereotypes and also avoid wrong stereotypes associated with English-speaking countries, cultures, and language. This can be better achieved if we implement appropriate critical thinking teaching methods in our language classes (see Rezaei, Derakhshan, \& Bagherkazemi, 2011). This understanding can highly motivate language learners too. For doing so, we should highlight the strong points in the Anglo-American culture, and at the same time pinpoint the potential sources of cultural clashes and differences to our learners (i.e. a contrastive approach). As Joseph (2001, p. 232) contends 'the spread of English does not necessarily entail the erosion of national or sub-national identities or cultures'.

Furthermore, the results can be illuminative for the proponents of critical pedagogy and reflective teaching/practice. Besides, learners' understanding of their own identities will foster their selves and their understandings of the world they live in. Into the bargain, the results are helpful and contributory at the age of globalization and how language learning can lead to a better understanding of the world in the current globalized 
world.

Experience shows that many language learners do not feel a sense of belonging to the community they are involved in. They should be made aware of their identity as language learners and how they should actualize this identity in class by being more active and participatory rather than being silent. The reason is that learners do not adopt a new identity as a language learner and regard the language class as their other classes like math class whereas language learning occurs mostly through socialization.

\section{Conclusion}

The results of this study show how the identity of an individual language learner in Iran changed after studying English for a long time. This study shows how the individual language learner is motivated toward the western language and culture and how this understanding has turned the learner into a more global individual knowing more than his peers about the world around him. As shown in the excerpts from Reza's life story and interviews, this change has made him more socialized in the world. The results from this individual showed how learners in higher levels of proficiency can be more enthusiastic about English language and culture. This internal desire can promote learners to higher rungs of language learning ladder.

One of the worries of language education programs is related to the age of the learners and which age is the best for learners to be exposed to English language and culture. The results on this individual show that after getting to the age of adulthood, learners can become critical about their sense of being and cannot be easily shaped through the discourses of power, i.e. the English language and culture, to the point of losing their own language, ethic and cultural identity. In this study, the adult language learner had a strong inclination toward the western language and culture and was mesmerized by its language and cultural norms. However, he was still in love with the norms of his own language and culture. This piece of evidence corroborates the existence of global understanding and thinking in the learner rather than imprisoning the learner to the local norms. This can be argued through globalization and the spread of language and cultural norms.

For the pronunciation preference, the learner was immensely in favor of American pronunciation. The reasons he mentioned and the researchers discovered were mainly related to the intelligibility, acceptability, and prestige of American pronunciation over other English accents. The learner considered speaking English with Persian accent as a way of projecting and revealing his Persian identity which was against his will when speaking English. The learner maintained that he was very interested in Persian language, but he did not like this side of his identity to be revealed when speaking English. This shows the learner's persistent love for his own language and culture which might be minimized when speaking English.

Regarding the culture for the medium of instruction, Reza showed that he was in favor of using western culture and did not like the use of Persian culture for teaching English. Having been in favor of English language and culture did not of course alienate him from his own language and culture. He has gone through a change of identity, but it has not made him crippled in his first language and culture. He still showed a great desire for knowing his own language and culture but he found Anglo-American culture very fascinating for language learning.

In conclusion, the individual language learner in this case study went through a reconstruction of identity because he changed from being an individual possessing a mindset of a local Persian to a more global individual. This is called identity reconstruction because the individual seems to have his first and second language and cultural norms and this change has not jeopardized any of these two. Having his first language and cultural identity in competence, Reza's identity is reconstructed with adopting English language and cultural norms.

\subsection{Limitations and future research}

In spite of all the claims made above about language and identity in this study, certain precautions should be 
made about this research. This study dealt with a complex human characteristic, i.e. identity, and in spite of all the efforts from the researchers, the data gathered might have suffered from some degrees of pollution due to its dealing with a personal construct. Furthermore, this study was situated and contextualized in Iran. Due to the exploratory nature of this study and its being primarily contextualized, the generalizability is limited to the Iranian context. There was only one participant in this study and subsequently the generalizability should not be made loosely to the whole country. Also, the researchers tried to be objective in this study. Nevertheless; some sources of subjectivity might have inevitably crept into the study due to the nature of the study.

This was a case study with only one participant, future studies on identity can be done in large scales using other research tools such as a validated questionnaire. Interested researchers can also investigate other aspects of English language learners' identity including their ethnic and gender identity. In order to have a complementary picture, we can investigate the difference between men and women in their language identity too. Another interesting research can investigate Persian migrants' identities abroad and how they might differ from the Persians in their own country.

Acknowledgement: The authors would like to express their thanks to Dariush Izadi for his invaluable comments on the early draft of this paper.

\section{References:}

Ashcroft, B., Griffiths, G., \& Tiffin, H. (1998). Key concepts in post-colonial studies. New York: Routledge. Bakhtin, M. (1981). The dialogic imagination: Four essays by M. M. Bakhtin. Austin, TX: University of Texas Press.

Bell, J. S. (2002). Narrative inquiry: More than just telling stories. TESOL Quarterly, 36(2), 207-213. http://dx.doi.org/10.2307/3588331

Belz, J. (2002). Second language play as a representation of the multi-competent self in foreign language study. Journal of Language, Identity and Education, 1(1), 13-39. http://dx.doi.org/10.1207/S15327701JLIE0101_3

Block, D. (2003). The social turn in second language acquisition. Edinburgh: Edinburgh University Press.

Block, D. (2006). Multilingual identities in a global city: London stories. London: Palgrave Macmillan.

Block, D. (2007a). The rise of identity in SLA research, post Firth and Wagner (1997). The Modern Language Journal, 91(5), 863-876. http://dx.doi.org/10.1111/j.1540-4781.2007.00674.x

Block, D. (2007b). Second language identities. London: Continuum.

Bourdieu, P. (1977). The economics of linguistic exchanges. Social science Information, 16(6), 645-668. http://dx.doi.org/10.1177/053901847701600601

Bourdieu, P. (1991). Language and symbolic power (J. B. Thompson, ed.; G. Raymond \& M. Adamson, trans.). Cambridge, UK: Polity Press (original work published in 1982).

Clandinin, D. J., \& Connelly, F. M. (2000). Experience and story in qualitative research: San Francisco: Jossey-Bass.

Duff, P. A. (2008). Case study research in applied linguistics research. New York: Lawrence Erlbaum.

Firth, A., \& Wagner, J. (1997). On discourse, communication, and (some) fundamental concepts in SLA research. The Modern Language Journal, 81(3), 285-300. http://dx.doi.org/10.1111/j.1540-4781.1997.tb05480.x

Ibrahim, A. E. K. M. (1999). Becoming black: Rap and hip-hop, race, gender, identity, and the politics of ESL learning. TESOL Quarterly, 33(3), 349-369. http://dx.doi.org/10.2307/3587669

Joseph, J. E. (2001). Globalization and the spread of English: The long perspective. Journal of Southeast Asian Education, 2(2), 212-240.

Joseph, J. E. (2004). Language and identity: National, ethnic, religious. Basingstoke: Palgrave Macmillan. 
Khatib, M. \& Rezaei, S.

Kanno, Y. (2003). Negotiating bilingual and bicultural identities: Japanese returnees betwixt two worlds. New Jersey: Lawrence Erlbaum Associates.

Lieblich, A., Tuval-Mashiach, R., \& Zilber, T. (1998). Narrative research: Reading, analysis and interpretation. Thousand Oaks, CA: Sage Publications.

Morgan, B. (2007). Poststructuralism and applied linguistics: Complementary approaches to identity and culture in ELT. In J. Cummins \& C. Davison (Eds.), International handbook of English language teaching (Vol. 2, pp. 949-968). Norwell, MA: Springer Publishers.

Morita, N. (2004). Negotiating participation and identity in second language academic communities. TESOL Quarterly, 38(4), 573-603. http://dx.doi.org/10.2307/3588281

Norton (Pierce), B. (1995). Social identity, investment, and language learning. TESOL Quarterly, 29(1), 9-31. http://dx.doi.org/10.2307/3587803

Norton, B. (1997). Language, identity, and the ownership of English. TESOL Quarterly, 31(3), 409- 429. http://dx.doi.org/10.2307/3587831

Norton, B. (2000). Identity and language learning. London: Longman.

Norton, B. (2011). The practice of theory in language classrooms. Issues in Applied Linguistics, 18(2), 1-10.

Norton, B., \& McKinney, C. (2011). An identity approach to second language acquisition. In D. Atkinson (Ed), Alternative approaches to second language acquisition (pp. 73-94). New York: Routledge.

Pavlenko, A. (2001). How am I to become a woman in an American vein? Transformations of gender performance in second language learning. In A. Pavlenko, A. Blackledge, I. Piller, \& M. Teutsch-Dwyer (Eds.), Multilingualism, second language learning, and gender (pp. 133-174). New York: Mouton de Gruyter. http://dx.doi.org/10.1515/9783110889406.133

Pavlenko, A. (2002). Poststructuralist approaches to the study of social factors in second language learning and use. In V. Cook (Ed.), Portraits of the L2 user (pp. 277-302). Clevedon, UK: Multilingual Matters.

Pavlenko, A. (2003). I never knew I was a bilingual: Reimagining teacher identities in TESOL. Journal of Language, Identity, and education, 2(4), 251-268. http://dx.doi.org/10.1207/S15327701JLIE0204_2

Pavlenko, A. (2007). Autobiographic narratives as data in Applied Linguistics. Applied Linguistics, 28(2), 163-188. http://dx.doi.org/10.1093/applin/amm008

Pavlenko, A., \& Blackledge, A. (eds.) (2004). Negotiation of identities in multilingual settings. Clevedon, UK: Multilingual Matters.

Pennycook, A. (1990). Toward a critical applied linguistics for the 1990s. Issues in Applied Linguistics, 1, 8-28. Pennycook, A. (1998). English and the discourses of colonialism. New York: Routledge.

Rezaei, S. (2012). Researching identity in applied linguistics. Journal of Language, Culture and Society, 35 , 45-51.

Rezaei, S., Derakhshan, A., \& Bagherkazemi, M. (2011). Critical thinking in language education. Journal of Language Teaching and Research, 2(4), 769-777. http://dx.doi.org/10.4304/jltr.2.4.769-777

Riley, P. (2007). Language, society and identity. London: Continuum.

Teutsch-Dwyer, M. (2002). (Re)constructing masculinity in a new linguistic reality. In A. Pavlenko, A.

Blackledge, I. Piller, \& M. Teutsch-Dwyer (eds.), Multilingualism, second language acquisition, and gender (pp. 175-98). New York: Mouton de Gruyter.

Weedon, C. (1997). Feminist practice and poststructuralist theory ( $2^{\text {nd }}$ ed.). Oxford: Blackwell.

Yin, R. K. (2003). Case study research: Design and methods $\left(3^{\text {rd }}\right.$ ed.). U.S.A.: Sage Publications, Inc. 


\section{Appendix A}

$>\quad$ Tell me about yourself

$>$ Your name

$>$ Academic background

$>\quad$ How long have you been studying English

$>\quad$ Have you been abroad? Where? And how long?

$>$ How did you learn English

Was English superior in status to your L1

$>\quad$ Social status

Your family and their probable significant roles in your academic life

$>\quad$ Why did you start learning English

$>\quad$ How did you perceive the culture of the English language? Did you consider it fascinating and superior to your own home culture?

$>\quad$ Did you try to be like English speaking people (e.g. American)

How far did you try to sound American or British and why?

$>\quad$ Did you consider learning English as prestigious?

What motivated you to become an English language learner?

What do you think was the main reason of your success in learning English?

$>\quad$ What other activities did you do in parallel with your English language learning to accelerate your learning

\section{Appendix B}

How do you think you are different now from the time you started learning English?

$>\quad$ How are the values in your language and culture different from those in English?

$>\quad$ How far have your ideologies and understandings of the English culture changed since you started learning it? Give some examples.

$>$ How far do you think your academic education has been influential in your developing a better understanding of the second language and the world around you?

$>\quad$ Do you think you have changed since you initially started learning? Do you think you are not the same as before? How? Give examples.

$>\quad$ Identity is related to who you are. For example your identity as a father or mother. Now can you tell me what identity you have as a language learner? Give me a sketch.

$>\quad$ How do you think differently now about the American or British culture since you first started learning English?

$>\quad$ How far do you think is your home cultural norms map onto the English cultural norms?

$>\quad$ Give me some examples of negative and positive changes in your personality and way of thinking after your studying English?

$>\quad$ Do you like to be associated and identified as American or British now when you are speaking English?

$>\quad$ Do you regard a person who speaks English fluently as more prestigious than you? Why? 
Khatib, M. \& Rezaei, S. 